\title{
Prevalence and Severity of Depression among Undergraduate Students in Karachi, Pakistan: A Cross Sectional Study
}

\author{
Sana Ghayas ${ }^{1 *}$, Sumbul Shamim ${ }^{1}$, Fakhsheena Anjum ${ }^{1}$ and Mehwish Hussain ${ }^{2}$ \\ ${ }^{1}$ Faculty of Pharmaceutical Sciences, Dow College of Pharmacy, ${ }^{2}$ Department of Research, Dow University of Health Sciences, \\ Karachi, Pakistan
}

*For correspondence: Email: sanaghayas7@hotmail.com

\begin{abstract}
Purpose: To highlight the prevalence and severity of depression among undergraduate students in public and private universities in Karachi, Pakistan.

Methods: In this cross-sectional study a total of 408 undergraduate students from both public and private universities in Karachi, Pakistan completed Zung Self-Rating Depression Scale (SDS) questionnaire to appraise the presence and extent of depression among the participants. Their sociodemographic characteristics such as age, gender and course of study as well as drug use data were also collected and analyzed.

Results: Depression prevalence was $53.43 \%$ (38.07\% for males and $61.00 \%$ for females). A significant disparity in the prevalence of depression across ethnicity was observed. Less than $50 \%(n=$ 163) of the students were satisfied with their duration of degree course work while 111 (27.20\%) participants were not sure about this. The intensity of depression increased with declining satisfaction level (Gamma $=0.264, p=0.001)$ which affected the performance and results of students during their studies. A majority of the participants ( $89 \%, n=358$ ) of our study have never used medicines to alter their mood.

Conclusion: The findings of this study highlight the importance of understanding the unique strains and mental health effect of university education on undergraduate students, especially female students.
\end{abstract}

Keywords: Depression, Undergraduate students, Mood alteration, Zung self-rating depression scale (SDS), Mental health, Risk assessment

Tropical Journal of Pharmaceutical Research is indexed by Science Citation Index (SciSearch), Scopus, International Pharmaceutical Abstract, Chemical Abstracts, Embase, Index Copernicus, EBSCO, African Index Medicus, JournalSeek, Journal Citation Reports/Science Edition, Directory of Open Access Journals (DOAJ), African Journal Online, Bioline International, Open-J-Gate and Pharmacy Abstracts

\section{INTRODUCTION}

Depression is a common mental disorder and would be one of the foremost causes of mental infirmity in the future [1-3]. Moreover, depression often comes with symptoms of anxiety and at its worst can lead to suicide. [4]. The youth and college students (18-24 years) are found to have susceptibility for depression possibly due to the load faced by them [5-7]. During this sociodemographic age rates of psychological distress and disorder are high [8]. WHO data [1] shows that the occurrence of most mood disorders and depression in Europe in the present age; an Australian national survey also supports this finding [9]. A study in Australia has shown that the challenges such as academic pressure, finances, social issues, etc are causes of depression [10,11]. Ang and Haun also found academic stress is significantly associated with depression [12]. 
For our study we used Zung Self Rating Depression Scale [13] for the diagnosis and assessment of depression. The Self-Rating Depression Scale (SDS) was designed as a short simple way of quantifying the severity of depression with psychological and physiological symptoms [14]. SDS is not only a reliable test for clinical and research use but it is also easy to apply in various samples [15]. This measure is considered both valid and reliable in various clinical and community settings and also has shown acceptable reliability in Asian communities [16,17]. This study compares depression severity in undergraduate students at different public and private sector Universities. The factors leading to depression are also highlighted to correlate them with occurrence and prevalence of depression in the students.

\section{EXPERIMENTAL}

\section{Participants and setting}

In this cross-sectional study, a total of 408 undergraduate students (females $=248,60.8 \%$ and males $=160,39.2 \%$ ) from different universities of Karachi volunteered to participate in the study from May 2012 - October 2012. Participants were recruited using a convenient sampling method.

\section{Measures}

Background data on age, gender, and degree studied were obtained through a questionnaire. Students were asked whether they used any medicines for mood alteration and if they did, then they were asked to mention the name of that medicine. This was sought to determine the rationality of drug use in depressive/non depressive students. Zung Self-Rating Depression Scale (SDS) [13] was applied to appraise the presence and extent of depression among the participants. Each questionnaire was explained to the participants by the researchers and was filled in their presence. In Zung Self Rating Depression Scale, there are 20 questions having the response range from 1-4 which were then transformed to numeric points to assess the level of depression [14]. Scores above 50 depict significant level of depression which is considered both valid and reliable $[16,17]$. The Zung Scale employed has high accuracy (80-90 $\%)$ and low sensitivity (70-80 \%) [13].

\section{Statistical analysis}

SPSS version 18.0 was employed for the analysis of data obtained. Reliability of the Zung
Self-Rating Depression Scale (SDS) was determined using Cronbach's alpha method. Descriptive statistics were used for the variables as appropriate. For detecting association between level of depression with academic, financial and medicine usage factors, chi-square test of independence was executed. Gamma statistic was obtained to measure strength of such association. To determine which items have more influence on creating depression, factor analysis was run with Promax rotation and those with Eigen values more than 1.0 were selected. Items showing factor loadings of at least 0.20 were chosen for new latent variables. The naming of the factors was done on the basis of variables with highest loadings and common characteristics. $P$ values less than 0.05 were considered to be significant.

\section{RESULTS}

Among 408 participants, majority ( $n=248 ; 60.8$ $\%$ ) were females in this study. The mean age of participants was $21.36 \pm 2.594$ years. Reliability of the stress questionnaire was $72.9 \%$. The average total stress score for the students was $42.82 \pm 6.361$. From the study it was found that $183(44.9 \%)$ students were mildly depressed and 35 (8.6\%) were moderately depressed and the depression prevalence was found to be 53.43 $\%$ (38.07 \% for males and $61.00 \%$ for females). A majority of the students ( $89 \%, n=358$ ) have never used medicine to alter their mood (Table 1).

The frequency of taking medicine was more by those who encountered mild depression rather moderate $(p<0.002)$. $(\mathrm{n}=19)$ of the students were using the drugs since three months. On asking about whether students sought doctor's advice for their condition, $65.4 \%$ (155/237) never did that and $\mathrm{n}=76(32.1 \%)$ sought doctor's advice frequently. This trend was found least in moderate depressed students $(p=0.019)$. Every two third of the students $(9.2 \%)$ felt better after using the medicines whereas students who were mildly depressed got reverse reaction of the medicine taken by them for altering their mood $(p$ $=0.02$ ) (Table 1). A variety of drugs were mentioned by the students in the questionnaire which they took for mood alteration; each one out of 10 participants used flouxetine and bromazepam for treating depression. It was also revealed that mefenamic acid was the most common drug taken by students in moderate depression to get relief from depression related pain as it is an analgesic (Fig. 1). 
Table 1: Gender distribution and use of medicine by students

\begin{tabular}{|c|c|c|c|c|c|c|c|}
\hline \multirow{2}{*}{\multicolumn{2}{|c|}{ Variable }} & \multicolumn{3}{|c|}{ Depression status } & \multirow{2}{*}{$\begin{array}{c}P \text { - } \\
\text { value }\end{array}$} & \multirow{2}{*}{ Gamma } & \multirow{2}{*}{ P (Gamma) } \\
\hline & & Normal & Mild & Moderate & & & \\
\hline \multirow{2}{*}{ Gender } & Female & $115(46.37 \%)$ & $111(44.76 \%)$ & $22(8.87 \%)$ & \multirow{2}{*}{0.917} & \multirow{2}{*}{-0.018} & \multirow{2}{*}{0.847} \\
\hline & Male & $73(46.79 \%)$ & $71(45.51 \%)$ & $12(7.69 \%)$ & & & \\
\hline \multirow{2}{*}{$\begin{array}{l}\text { Use of } \\
\text { medicine } \\
\text { for mood } \\
\text { change }\end{array}$} & Frequently & $06(18.18 \%)$ & $25(75.76 \%)$ & $02(6.06 \%)$ & \multirow{2}{*}{0.002} & \multirow{2}{*}{0.443} & \multirow{2}{*}{0.001} \\
\hline & Regularly & $03(30.00 \%)$ & $05(50.00 \%)$ & $2(20.00 \%)$ & & & \\
\hline \multirow{3}{*}{$\begin{array}{l}\text { Frequency } \\
\text { of use of } \\
\text { Medicine }\end{array}$} & Once a Day & 06(31.58 \%) & $10(52.63 \%)$ & $3(15.79 \%)$ & \multirow{3}{*}{0.457} & \multirow{3}{*}{0.244} & \multirow{3}{*}{0.427} \\
\hline & $\begin{array}{l}\text { Twice a } \\
\text { Day }\end{array}$ & $00(0.00 \%)$ & $05(71.43 \%)$ & $2(28.57 \%)$ & & & \\
\hline & $\begin{array}{l}\text { Thrice a } \\
\text { day }\end{array}$ & $01(33.33 \%)$ & $02(66.67 \%)$ & $0(0.00 \%)$ & & & \\
\hline \multirow{4}{*}{$\begin{array}{l}\text { Duration of } \\
\text { use of } \\
\text { medicine }\end{array}$} & 3 months & 03(15.79 \%) & $13(68.42 \%)$ & $3(15.79 \%)$ & \multirow{4}{*}{0.509} & \multirow{4}{*}{-0.081} & \multirow{4}{*}{0.74} \\
\hline & 6 months & 01(16.67 \%) & $03(50.00 \%)$ & $2(33.33 \%)$ & & & \\
\hline & 1 year & $00(0.00 \%)$ & $06(100.00 \%)$ & $0(0.00 \%)$ & & & \\
\hline & $>1$ year & $03(27.27 \%)$ & $06(54.55 \%)$ & $2(18.18 \%)$ & & & \\
\hline \multirow{3}{*}{$\begin{array}{l}\text { Seek } \\
\text { doctor's } \\
\text { advice }\end{array}$} & Never & $68(43.87 \%)$ & $68(43.87 \%)$ & $19(12.2 \%)$ & \multirow{3}{*}{0.019} & \multirow{3}{*}{0.091} & \multirow{3}{*}{0.436} \\
\hline & Frequently & $24(31.58 \%)$ & $46(60.53 \%)$ & $6(7.89 \%)$ & & & \\
\hline & Regularly & $4(100.00 \%)$ & $00(0.00 \%)$ & $0(0.00 \%)$ & & & \\
\hline \multirow{3}{*}{$\begin{array}{l}\text { Effect of } \\
\text { use of } \\
\text { medicine }\end{array}$} & Better & $14(38.89 \%)$ & $16(44.44 \%)$ & $6(16.67 \%)$ & \multirow{3}{*}{0.02} & \multirow{3}{*}{0.495} & \multirow{3}{*}{0.018} \\
\hline & Same & $00(0.00 \%)$ & $12(92.31 \%)$ & $1(7.69 \%)$ & & & \\
\hline & Reverse & $00(0.00 \%)$ & $04(80.00 \%)$ & $1(20.00 \%)$ & & & \\
\hline
\end{tabular}

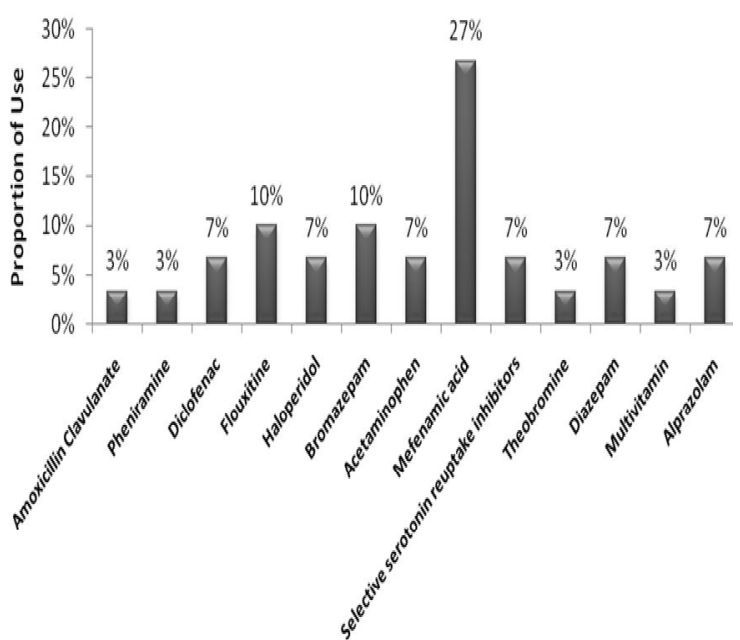

Figure 1: Distribution of medicines taken to alter mood

The study revealed that less than 50 percent of the students $(n=163)$ were satisfied with their duration of degree course work whereas $\mathrm{n}=$ $111(27.20 \%)$ participants were not sure about this. The intensity of depression also increased with declining satisfaction level of students for the degree course work (Gamma $=0.264, p=$ $0.001)$ which affects the performance and results of students during their studies. Similar proportional distribution was observed in the categories of the opinion by students whether they were getting enough time for their studies or not (40\% for both). While $20 \%$ of the students were not sure about the attainment of time for their studies (Table 2). The responses of the question about satisfaction with teaching method/mode displayed the similar pattern (Table 2).

The proportion of depression was found less in students satisfied with the teaching method/mode than in unsatisfied students $(p=$ 0.001). Gamma value also indicated that enhanced satisfaction level lead to less depression among students (Gamma $=0.321, p$ $<0.0005) . n=174(46.2 \%)$ students were bothered in their daily activities due to study load though the proportions of level of depression due 
Table 2: Academic factors relating to status of depression

\begin{tabular}{|c|c|c|c|c|c|c|c|}
\hline & & \multicolumn{3}{|c|}{ Depression status } & \multirow{2}{*}{$\begin{array}{c}P \text { - } \\
\text { value }\end{array}$} & \multirow{2}{*}{ Gamma } & \multirow{2}{*}{$P$ (Gamma) } \\
\hline & & Normal & Mild & Moderate & & & \\
\hline \multirow{3}{*}{$\begin{array}{l}\text { Satisfaction } \\
\text { with degree } \\
\text { course } \\
\text { duration }\end{array}$} & Yes & $91(55.83 \%)$ & $63(38.65 \%)$ & $9(5.52 \%)$ & \multirow{3}{*}{0.019} & \multirow{3}{*}{0.264} & \multirow{3}{*}{0.001} \\
\hline & No & $39(46.43 \%)$ & $38(45.24 \%)$ & $7(8.33 \%)$ & & & \\
\hline & $\begin{array}{l}\text { Not } \\
\text { Sure }\end{array}$ & $41(36.94 \%)$ & $55(49.55 \%)$ & $15(13.51 \%)$ & & & \\
\hline \multirow{3}{*}{$\begin{array}{l}\text { Enough time } \\
\text { for studies }\end{array}$} & Yes & $90(58.06 \%)$ & $54(34.84 \%)$ & $11(7.10 \%)$ & \multirow{3}{*}{0.000} & \multirow{3}{*}{0.314} & \multirow{3}{*}{$<0.001$} \\
\hline & No & $72(48.32 \%)$ & $66(44.30 \%)$ & $11(7.38 \%)$ & & & \\
\hline & $\begin{array}{l}\text { Not } \\
\text { Sure }\end{array}$ & $19(26.76 \%)$ & $41(57.75 \%)$ & $11(15.49 \%)$ & & & \\
\hline \multirow{3}{*}{$\begin{array}{l}\text { Satisfaction } \\
\text { with teaching } \\
\text { method/mode }\end{array}$} & Yes & $87(61.27 \%)$ & $47(33.10 \%)$ & $8(5.63 \%)$ & \multirow{3}{*}{0.001} & \multirow{3}{*}{0.321} & \multirow{3}{*}{$<0.001$} \\
\hline & No & $64(43.24 \%)$ & $70(47.30 \%)$ & $14(9.46 \%)$ & & & \\
\hline & $\begin{array}{l}\text { Not } \\
\text { Sure } \\
\end{array}$ & $29(34.12 \%)$ & $45(52.94 \%)$ & $11(12.94 \%)$ & & & \\
\hline \multirow{3}{*}{$\begin{array}{l}\text { Study load } \\
\text { bothers daily } \\
\text { activities }\end{array}$} & Yes & $88(50.57 \%)$ & $68(39.08 \%)$ & $18(10.34 \%)$ & \multirow{3}{*}{0.101} & \multirow{3}{*}{0.094} & \multirow{3}{*}{0.233} \\
\hline & No & $72(51.80 \%)$ & $58(41.73 \%)$ & $9(6.47 \%)$ & & & \\
\hline & $\begin{array}{l}\text { Not } \\
\text { Sure } \\
\end{array}$ & $22(34.38 \%)$ & $36(56.25 \%)$ & $6(9.38 \%)$ & & & \\
\hline \multirow{3}{*}{$\begin{array}{l}\text { Able to meet } \\
\text { study finance }\end{array}$} & Yes & $117(51.09 \%)$ & $93(40.61 \%)$ & $19(8.30 \%)$ & \multirow{3}{*}{0.213} & \multirow{3}{*}{0.129} & \multirow{3}{*}{0.133} \\
\hline & No & $32(43.24 \%)$ & $38(51.35 \%)$ & $4(5.41 \%)$ & & & \\
\hline & $\begin{array}{l}\text { Not } \\
\text { Sure }\end{array}$ & $31(43.06 \%)$ & $31(43.06 \%)$ & $10(13.89 \%)$ & & & \\
\hline \multirow{3}{*}{$\begin{array}{l}\text { Regular time } \\
\text { for preparation } \\
\text { of exam }\end{array}$} & Yes & $32(50.00 \%)$ & $26(40.63 \%)$ & $6(9.38 \%)$ & \multirow{3}{*}{0.323} & \multirow{3}{*}{0.009} & \multirow{3}{*}{0.923} \\
\hline & No & $35(52.24 \%)$ & $23(34.33 \%)$ & $9(13.43 \%)$ & & & \\
\hline & $\begin{array}{l}\text { Not } \\
\text { Sure }\end{array}$ & $114(47.90 \%)$ & $108(45.38 \%)$ & $16(6.72 \%)$ & & & \\
\hline
\end{tabular}

to this were not consistent $(p=0.101) .20 \%(\mathrm{n}=$ 74) students were not able to meet finances regarding their studies however; they were bit less depressed than those who met their finances. The preparation time for exams was not found to be fixed for most of the students ( $\mathrm{n}=$ 238, $58.33 \%$ ). Also, depression level was not significantly associated with preparation schedule $(p=0.323)$ (Table 2).

The determination of most significant symptoms for depression in our region was determined by factor analysis. For naming the factors, rule of thumb of factor analysis was used. According to this rule that if there were two variables which contradict ideas then a name is given to the factor with respect to variable with higher loading or with variables which were more correlated. Since all other variables in the factor were contradicting to each other except the last ones so the name is given as "being anxious", though it was firstly thought to name as "appetite problem". So the variable "appetite problem" is replaced now by the variable "being anxious".
The Keyser - Meyer - Olkin (KMO) measure was 0.743 which indicated that items were factorable. The analysis revealed that factors "Faster Heart Beat", "Feeling of down-hearted and blue", "Full Life", "Crying Spells", "Usual Irritation" and "Enjoying thing as usual" accounted much of the variation. Thus, Factor 1 renamed as "Down Hearted Behavior", Factor 2 comprised of "Easy to Make Decisions", "Easy things to do" and "Feeling of being useful and needed"; hence, it was considered to be "Confidence to Life behavior". Third factor was named "Peaceful Mind" after observing three factors included in it i.e. "Morning is when I feel best", "Feel hopeful about future" and "Clear Mind as usual". "I get tired for no reason", "Others are better off", " Restless", "Trouble in Sleeping" and "Eating as much as usual" contributed their variations in Factor 4; it was named as "Nervousness in daily routine". Factor 5 was "Being anxious" as opting to contain positive association with items "I have crying spells and feel like it" and "My heart beat faster than usual" but negative with "My mind is as clear as it used to be". This factor also 
Table 3: Factor Loadings for significant symptoms of depression among students

\begin{tabular}{|c|c|c|c|c|c|}
\hline Variable & $\begin{array}{l}\text { Down } \\
\text { hearted } \\
\text { behavior }\end{array}$ & $\begin{array}{l}\text { Confidence } \\
\text { in life } \\
\text { behavior }\end{array}$ & $\begin{array}{l}\text { Peaceful } \\
\text { mind }\end{array}$ & $\begin{array}{l}\text { Nervousness } \\
\text { in daily } \\
\text { routine }\end{array}$ & $\begin{array}{l}\text { Being } \\
\text { anxious }\end{array}$ \\
\hline $\begin{array}{l}\text { I still enjoy the things I used to do. } \\
\text { I feel down-hearted and blue. }\end{array}$ & $\begin{array}{l}0.82 \\
0.43\end{array}$ & & & & \\
\hline My life is pretty full. & 0.35 & 0.26 & & & \\
\hline I have crying spells or feel like it. & 0.34 & & & & 0.27 \\
\hline My heart beats faster than usual. & 0.33 & & & 0.27 & 0.21 \\
\hline $\begin{array}{l}\text { I am more irritable than usual. } \\
\text { I feel that I am useful and needed. } \\
\text { I find it easy to make decisions. }\end{array}$ & 0.22 & $\begin{array}{l}0.71 \\
0.56\end{array}$ & & & 0.33 \\
\hline $\begin{array}{l}\text { I find it easy to do the things I used } \\
\text { to. }\end{array}$ & & 0.53 & & & \\
\hline I feel hopeful about the future. & & & 0.79 & & \\
\hline $\begin{array}{l}\text { Morning is when I feel the best. } \\
\text { My mind is as clear as it used to be. }\end{array}$ & & & $\begin{array}{l}0.67 \\
0.39\end{array}$ & $\begin{array}{l}-0.23 \\
0.23\end{array}$ & -0.24 \\
\hline $\begin{array}{l}\text { I feel that others would be better off, } \\
\text { if I were dead. }\end{array}$ & 0.28 & & & 0.63 & \\
\hline I have trouble sleeping at night. & & & & 0.47 & \\
\hline I am restless and can't keep still. & & & & 0.37 & \\
\hline I get tired for no reason. & & & & 0.26 & \\
\hline I eat as much as I used to. & & & & 0.23 & \\
\hline I have trouble with constipation. & & & & & 0.22 \\
\hline I notice that I am losing weight. & & & & & 0.18 \\
\hline Cronbach's Alpha & 0.66 & 0.62 & 0.62 & 0.49 & 0.09 \\
\hline
\end{tabular}

Note: Factor loadings $>0.20$ were suppressed

contained items "I have trouble with constipation" and "I notice that I am losing weight". However, since factor loadings of these items were comparatively low then other common variables so these were omit to consider in naming the factor. The internal consistency of each factor was measured by Cronbach's alpha. Thereliability was moderate for first four factors though the factor of "Being anxious" had poor reliability. Thus, this factor cannot be useful for assessing the depression scores among students of the region (Table 3 ).

\section{DISCUSSION}

In this study, $53.43 \%$ of undergraduate students showed signs of potential mental health problems. In a similar study carried out in Turkey, overall depression prevalence was $26.2 \%$ which is much lower than what we found [18]. The findings of our study indicate higher prevalence of depression in the female students than males with significant disparity in the prevalence of depression across ethnicity. This is similar to the results of a study in 1999 in which the lifetime depression incidence in the population was about $10 \%$ for men and $20 \%$ for women [19]. A high burden of depression among females than males was also reported in the Global Burden of Disease study [3].
Irrational use of medicines among undergraduates to alter their mood has been observed in this study. The frequency of taking medicine was more for those who encountered mild depression rather moderate $(p<0.002)$. Even, few students with normal status of depression also took medicine to alter their mood and majority of the students did not sought doctor's advice for their condition. Every two third of the students felt better after using the medicines whereas $5(9.2 \%)$ students who were mildly depressed got reverse reaction of the medicine taken by them $(p=0.02)$. These results are also pointing towards the need of awareness among students, for avoiding self medication to enhance rational use of drugs.

Academic activities was significantly associated with the academic activities i.e. studies, assignments, exams, etc and their associated load. The density of non-depressed students was found more in the category of participants who got enough time for their studies which implies that those students have more chances of getting depressed who have not sufficient time for their studies. MacGeorge et al and Ang \& Haun also found that academic stress was significantly associated with depression [20,12]. We anticipated that students who were not able to meet finances regarding their studies would show increased level of depression but results revealed the opposite. 


\section{Limitations of the study}

The sample in this study was randomly selected only from universities of Karachi and the findings cannot be generalized to all Pakistani students. This is only a preliminary report and requires further longitudinal, more accurate investigations. A future study may be required to examine the factors related to the genetic and environment variables.

\section{CONCLUSION}

The findings of this study can guide university administrators, counselors, governmental and private agencies to understand the state of mental health among undergraduate students during their studies and also in their field work. Some intervention programs such as stress management, time management, study techniques and coping skills workshop should be planned for the targeted groups with mild to moderate problems.

\section{ACKNOWLEDGEMENT}

The authors thank Prof $\mathrm{Dr}$ Nazeer Khan, Chairman, Research Department, Dow University of Health Sciences, who assisted with ensuring the integrity of the data as well as accuracy of the data analysis.

\section{REFERENCES}

1. WHO. The World Health Report 2000 - health systems: improving performance. Geneva, World Health Organization, 2000.

2. Murray CJ, Lopez AD. Alternative projections of mortality and disability by cause 1990-2020: Global burden of disease study. Lancet 1997; 349: 1498-1504.

3. Ustun TB, Ayuso-Mateos JL, Chatterii S, Mathers C, Murray CJL. Global burden of depressive disorders in the year 2000. Br J Psychiatry 2004; 184: 386-392.

4. World Health Organization, World Suicide Prevention Day 2012. http://www.who.int/mediacentre/events/ annual/world_suicide_prevention_day/en/Accessed 16.6.2012

5. Kim YS, Koh YJ, Leventhal B. School bullying and suicidal risk in Korean middle school students. Pediatrics 2005; 115: 357-363.

6. Klomek AB, Marrocco F, Kleinman M, Schonfeld IS, Gould MS. Peer victimization, depression and suicidiality in adolescents. Suicide Life Threat Behav 2008; 38: 166-180.
7. Thurber S, Snow M, Honts CR. The Zung Self-Rating Depression Scale: Convergent Validity and Diagnostic Discrimination. Assessment 2002; 9: 401405.

8. Adlaf EM, Gliksman L, Demers A, Newton-Taylor B. The prevalence of elevated psychological distress among Canadian undergraduates: Findings from the 1998 Canadian campus survey. J Am Coll Health 2001; 50 : 67-72.

9. Korten A, Henderson S. The Australian National Survey of Mental Health and Well- Being. Br J Psychiatry 2000; 177: 325-330.

10. Jones NP, Papadakis AA, Hogan CM, Strauman TJ. Over and over again: Rumination, reflection, and promotion goal failure and their interactive effects on depressive symptoms. Behaviour Research \& Therapy 2009; 47: 254-259.

11. Papadakis AA, Prince RP, Jones NP, Strauman TJ. Selfregulation, rumination, and vulnerability to depression in adolescent girls. Dev Psychopathol 2006; 18: 815829.

12. Ang RP, Haun VS. Relationship between academic stress and suicidal ideation: Testing for depression as a mediator using multiple regressions. Child Psychiatry Hum Dev 2006; 37: 133-143.

13. Zung WWK. A self-rating depression scale. Archives of General Psychiatry 1965; 12: 63-70.

14. Shafer A. Meta-analysis of the factor structures of four depression questionnaires: Beck, CES-D, Hamilton, and Zung. J Clin Psychol 2006; 62: 123-146.

15. Fountoulakis $K N$, lacovides A, Samolis $S$, Kleanthous $S$, Kaprinis SG, Karinis SG, Bech P. Reliability, Validity and Psychometric Properties of the Greek Translation of the Zung Depression Rating Scale. BMC Psychiatry 2001; 1: 6.

16. Smith T, Rosenstein I, Granaas M. Intake screening with the Self-Rating Depression Scale in a university counseling center. J Coll Couns 2001; 4: 133-141.

17. Weining C Chang, Jessie Bee Kim Koh. A Measure of Depression in a Modern Asian Community: Singapore. Depression Research and Treatment 2012; 8 pages.

18. Bostanci M, Ozdel O, Oguzhanoglu NK, Ozdel L, Ergin A, Ergin N, Atesci F, Karadag F. Depressive Symptomatology among University Students in Denizli, Turkey: Prevalence and Sociodemographic Correlates. Croat Med J 2005; 46: 96-100.

19. Beers M, Berkow R. Merck Manual - 17th Ed. Centennial Edition. [Database/electronic text on the Internet]. West Point, PA: Merck \& Co., Inc., 2005. 1999. [Cited 6.6.2006] Available from: http://online. statref.com/document. aspx ?fxid $=37 \&$ docid $=284$.

20. MacGeorge E, Samter W, Gillihan S. Academic stress, supportive communication, and health. Commun Educ 2005; 54: 365-372. 